\title{
ULOGA SMRTI U NJEMAČKOJ FILOZOFIJI EGZISTENCIJE MEĐURATNOGA PERIODA \\ I NJEZINA RECEPCIJA U MISLI STJEPANA ZIMMERMANNA
}

\section{Matko Globačnik}

UDK: 141.32(430)“192/193“:125

Izvorni znanstveni članak

Sažetak: Smrt ima važnu ulogu u misli glavnih predstavnika njemačke filozofije egzistencije međuratnoga perioda, Martina Heideggera i Karla Jaspersa. U Heideggerovoj ona je kraj „bitka-u-svijetu“, a u Jaspersovoj „granična situacija“ u kojoj se naslućuje ono transcendentno. Time smrt opusom obojice mislilaca znatno utječe na filozofski pravac obilježen tjeskobom, nesigurnošću, potragom za smislom čovjekova postojanja i njegovim položajem u svijetu. Istim se pitanjima u međuratnoj Jugoslaviji bavio izuzetno plodan katolički filozof i teolog Stjepan Zimmermann. Još prije Heideggera (Kant und das Problem der Metaphysik, 1929.) i Jaspersa, monografijom zaokružujući višegodišnje bavljenje filozofijom Immanuela Kanta (Kant i neoskolastika, 1920./1921.) te polazeći od njegova napada na tradicionalnu metafiziku, Zimmermann se s pozicije katoličkog intelektualca vjernog skolastičkoj tradiciji bavio Kantovom problematikom koja je presudno utjecala na razvoj kontinentalne filozofije, a time i filozofije egzistencije. S potonjom je podrobno bio upoznat te će se s njome kritički razračunati u opsežnom djelu Jaspersov egzistencijalizam, koje je do danas ostalo neobjavljeno u punom opsegu. U cilju rasvjetljavanja idejno-povijesnih izvora spomenutoga djela, u članku se pokušava sistematski razjasniti ulogu smrti u filozofiji Heideggera i Jaspersa te utjecaj rečene teme na misao Stjepana Zimmermanna u povijesnom kontekstu međuratnoga perioda, u kojemu su djelovala sva trojica mislilaca.

Ključne riječi: Karl Jaspers, Martin Heidegger, Stjepan Zimmermann, smrt, filozofija egzistencije, novokantovstvo, katolička teologija

\section{UVOD}

uprotno popularnom uvjerenju, u povijesti filozofije smrt nije bila tema o kojoj se mnogo raspravljalo ili sistematski pisalo. ${ }^{1}$ Njezina je uloga bila važnija u filozofiji pesimističkih i egzistencijalističkih mislilaca 19. stoljeća, koji su imali znatnog utjecaja na filozofiju egzistencije koja se javlja nakon Prvoga svjetskog rata u Njemačkoj. Unatoč me-

$1 \quad$ Iako, naravno, brojna pitanja koja su se mnogo raspravljala u filozofiji tijekom njezine povijesti imaju implikacije za temu smrti. Usp. Ben Bradley - Fred Feldman - Jens Johansson, „Introduction. Philosophy of Death“, The Oxford Handbook of Philosophy of Death (ur. Ben Bradley, Fred Feldman i Jens Johansson), Oxford 2013., 1-4. 


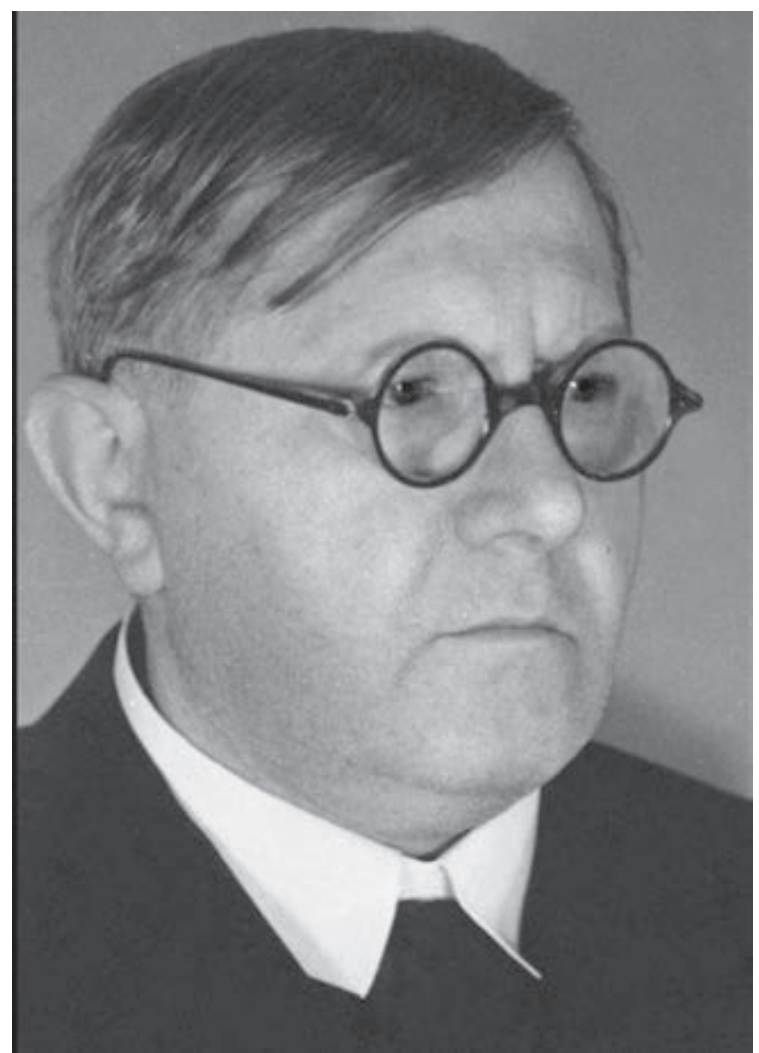

Sl. 1. Stjepan Zimmerman

đusobnim razlikama i drugačijem načinu pripadanja tome filozofskom pravcu, njegovi znameniti predstavnici Martin Heidegger i Karl Jaspers dobrim su dijelom oblikovali svoja promišljanja o biti ljudske egzistencije u odnosu prema vlastitu shvaćanju smrti.

Smrt također ima znatnu ulogu u katoličkoj teologiji, a vjerojatno je najznamenitiji hrvatski katolički mislilac međuratnoga perioda bio Stjepan Zimmermann. U njegovu bogatu opusu, znatno obilježenom kršćanskim shvaćanjem složenog odnosa života i smrti, prvo mjesto po opsegu zauzima upravo djelo Jaspersov egzistencijalizam, koje do danas nije u potpunosti objavljeno, niti je točnije utvrđeno u kojem je vremenu ono bilo pisano i ostavljeno u stanju u kakvu se danas nalazi. ${ }^{2}$

Cilj je ovoga rada stoga istraživanjem uloge smrti u njemačkoj filozofiji egzistencije i njezine recepcije u misli Stjepana Zimmermanna u povijesnom kontekstu međuratnoga perioda pridonijeti rasvjetljavanju idejno-povijesnih izvora djela Jaspersov egzistencijalizam. Prije razmatranja teme smrti uzimaju se dvije ključne točke koje su relevantne za nju te su zajedničke i egzistencijalistima i Zimmermannu, a to su problem (novo)kantovskog nasljeđa te djelovanje u polju tada relativno novih znanosti - psihologije, odnosno psihijatrije.

\section{NovoKantovsKo NASLJEĐE I ULOGa SMRTI U NJEMAČKOJ FILOZOFIJI EGZISTENCIJE}

Najsnažniji filozofski pravac u srednjoj Europi u drugoj polovini 19. i na početku 20. stoljeća bio je novokantovstvo. Interpretirajući filozofiju Immanuela Kanta, središnjeg mi-

$\overline{2}$ Zbog političkih okolnosti, brojna su Zimmermannova djela donedavno ostala neobjavljena. Ipak, on se trudio, oslanjajući se na osobe od povjerenja, da u svakom slučaju ta djela ipak ugledaju svjetlo dana. Usp. Blaž JuRIŠić, Dnevnik Blaža Jurišića (prir. Biserka Rako), Zagreb 1994., 199. Jedan od prvih koji je upozorio na djelo Jaspersov egzistencijalizam u Zimmermannovoj ostavštini te pružio njegov kratak opis i vlastitu interpretaciju konteksta njegova nastanka bio je Ivan Čehok. Usp. Ivan ČEHок, „Filozofijska ostavština Stjepana Zimmermanna“, Prilozi za istraživanje hrvatske filozofske baštine, 19/1993., 196-201. Do danas objavljen je samo prvi svezak: Stjepan Zimmermann, Jaspersov egzistencijalizam. Karl Jaspers prema religiji, sv. 1, Zagreb 2002. Nažalost, priređivač Zeljko Pavić (str. XI-XV) nije dublje ulazio u pokušaj datacije nastanka djela. Njegov izvornik (pa tako i drugi svezak) čuva se u Nadbiskupijskom arhivu u Zagrebu (dalje: NAZ) u ostavštini Stjepana Zimmermanna (dalje: SZ), kutija „Jaspers“. 
slioca moderne njemačke filozofije, ponajprije kao teoriju spoznaje koja istražuje logičke procese mišljenja, odnosno transcendentalne uvjete mogućnosti spoznaje, zrelo novokantovstvo budućnost filozofije vidjelo je u epistemologiji koja bi djelovala kao logika znanosti. Novokantovski optimizam u pogledu mogućnosti postizanja boljeg života političkom borbom na ovome svijetu nije potiskivao samo stara metafizička pitanja koja su prelazila granice iskustva, poput postojanja Boga ili besmrtnosti duše, već i suprotstavljene filozofske pravce poput egzistencijalizma Sørena Kierkegaarda te pesimizma Arthura Schopenhauera i Friedricha Nietzschea. ${ }^{3}$ Početkom 20. stoljeća njemačkom filozofijom dominirale su tri novokantovske škole: marburška, čiji su najznamenitiji predstavnici bili Hermann Cohen, Paul Natorp i Ernst Cassirer, zatim badenska s predstavnicima Wilhelmom Windelbandom, Heinrichom Rickertom i Emilom Laskom te nova Friesova škola, kojoj je pripadao Leonard Nelson, pri čemu je novokantovska tradicija bila jaka i u drugim sveučilišnim centrima poput Strassbourga i Berlina. Međutim, mnogi su novokantovci fanatično podupirali službenu njemačku politiku u Prvome svjetskom ratu, vezujući svoju sudbinu s njegovim ishodom. Njemački poraz 1918. i turbulentna zbivanja u poraću, kada već brojni znameniti novokantovci više nisu bili živi, znatno su uzdrmali dominaciju novokantovstva, a njegov optimizam sada je bio laka meta za filozofske pravce poput pesimizma. ${ }^{4}$

Dvojica mladih mislilaca, Martin Heidegger i Karl Jaspers, bila su također kritična prema novokantovstvu. Heidegger, koji je u međuraću predavao filozofiju u Marburgu i Freiburgu, u lipnju 1922. poručio je Jaspersu da je potrebna kritika dosadašnje ontologije „u njenu korijenu u grčkoj filozofiji, posebno Aristotela, čija je ontologija (već ovaj pojam ne odgovara) jednako snažno živa u Kanta i čak Hegela, kao kod kakva srednjovjekovnog skolastičara“. Obojici im je posebno odbojna bila novokantovska akademska filozofija koju je zastupao, primjerice, Windelband, iako su priznavali oštroumne mislioce poput Cassirera. ${ }^{5}$ Od dvojice mislilaca koji su posebno utjecali na Heideggera i Jaspersa, jedan je razvijao fenomenologiju nezavisnu od teorija novokantovstva (Edmund Husserl), a drugi (Max Scheler) bio je kritičar Kantove filozofije. Scheler je još za vrijeme rata (1916.) dovršio utjecajno djelo pod naslovom Der Formalismus in der Ethik und die materiale Wertethik, pokušavajući utemeljiti materijalnu vrijednosnu etiku i kritizirajući formalizam Kantove etike te tvrdeći da su vrijednosti samostalni fenomeni, a ne apstrakcije iz materijalnih odredbi volje. ${ }^{6}$ Međutim, na Heideggera će najviše utjecaja imati kasna Schelerova filozofija, pogotovo djelo

3 Frederick Charles Beiser, The Genesis of Neo-Kantianism, 1796 - 1880, Oxford 2014., najnovija je sinteza o izvorima i povijesti novokantovstva, koja prati razvoj i konačnu pobjedu epistemološke interpretacije Kantove filozofije nasuprot psihologističkoj. O odnosu novokantovaca prema pesimističkim misliocima v. 398-421.

4 O historicističkoj, nihilističkoj i pesimističkoj kritici novokantovstva u Weimarskoj Republici v. Frederick Charles Beiser, „Weimar Philosophy and the Fate of Neo-Kantianism“, Weimar Thought. A Contested Legacy (ur. Peter A. Gordon i John P. McCormick), Princeton 2013., 115-132. Međutim, Beiser ne spominje Edmunda Husserla i Maxa Schelera kao značajne mislioce Weimarske Republike, koji su znatno utjecali na Heideggera i Jaspersa.

5 Martin Heidegger - Karl Jaspers, Briefwechsel 1920-1963, Frankfurt am Main 1990., 27, 31, 71-72, 74, 89.

6 Max Scheler, Gesammelte Werke, sv. 2: Formalismus in der Ethik und materiale Wertethik, Bern 1966., 29-65. Kritika Kantove etike kao formalističke ima vrlo dugu tradiciju, a nju je započeo još Kantov suvremenik H. A. Pistorius. O tome v. Matko GlobaČNik, Izazov skepticizma. Utjecaj Humeove metafizike i moralne filozofije u Europi 18. stoljeća, Zagreb 2016., 369-381, 403-405, 424-426. Ukratko o Husserlu v. Ulrich ClaesGes, „Husserl, Edmund“, Neue Deutsche Biographie (dalje: NDB), sv. 10, Berlin 1974., 87-89; o Scheleru v. Wolfhart Henckmann, „Scheler, Max“, NDB, sv. 22, Berlin 2005., 644-646. 
Die Stellung des Menschen im Kosmos (1928.) jer je već samo pitanje o čovjekovu položaju u kozmosu bilo ukorijenjeno u biti specifično ljudskog načina egzistiranja.?

Upravo je Heideggerovo djelo Kant und das Problem der Metaphysik (1929.) bilo posvećeno Scheleru, štoviše, njegov sadržaj bio je predmet Heideggerova posljednjeg razgovora sa Schelerom. Ono je stajalo u najužoj vezi s Heideggerovim najpoznatijim djelom Sein und Zeit (1927.), koje je, pak, bilo posvećeno Husserlu. Heideggerov je Kant, nasuprot novokantovcima, ponudio radikalnu reinterpretaciju kritičke misli filozofa iz Königsberga. ${ }^{8}$ U spomenutoj se knjizi Kantov kritički projekt ne interpretira kao ograničavanje tradicionalne metafizike s ciljem preoblikovanja filozofije u epistemologiju, nego kao zasnivanje „fundamentalne ontologije“ koja u tradiciji starogrčke filozofije treba pripremiti temelj za „prirodi ljudi pripadnu“ metafiziku. Kant je htio razriješiti pitanje unutarnje mogućnosti transcendentalne filozofije koja nije epistemologija, tvrdi Heidegger, nego opća metafizika ili ontologija, a rješenje vidio je u sintetičkim sudovima a priori. ${ }^{9}$ Dakako da je takva interpretacija Kanta bila nadogradnja na Sein und Zeit, u čijim je temeljima upravo bila rehabilitacija bitka od njegova povijesnog „zaborava“, odnosno fundamentalna ontologija koja istražuje smisao bitka, ${ }^{10}$ a to je istraživanje Heideggera odvelo u definiranje „tubitka“ (Dasein) odnosno specifično ljudskog načina egzistiranja, što je uključivalo i temu smrti. U Heideggerovoj je filozofiji tubitak nepotpun jer mu je otvoreno područje mogućnosti (što Heidegger naziva brigom) na koje je on usmjeren. Najvlastitija je mogućnost ljudske egzistencije smrt jer je, s obzirom na neiskusivost smrti drugoga, ona uvijek samo njezina. Smrt označava kraj bitka-u-svijetu, svijeta u koji je tubitak bačen i koji u egzistencijalnom strahu otkriva svoju bačenost. Heideggerovo ontološko određenje smrti, za koje smatra da leži u temelju i njezina empirijsko-znanstvenog shvaćanja, tvrdi da je ona izvjesna mogućnost nemogućnosti svakog odnosa prema svakom egzistiranju, a iz te izvjesne mogućnosti proizlazi tjeskoba, ali i svijest pojedinačnosti i cjelovitosti ljudske egzistencije. „Trčanje naprijed“ (Vorlaufen) u mogućnost smrti ljudskoj egzistenciji omogućuje oslobođanje brige, tj. odnosa prema izvjesnoj mogućnosti smrti zbog kojeg je nepotpuna i postajanje njome samom u strašnoj slobodi k smrti, zaključuje Heidegger. ${ }^{11}$

Jaspersov je put u filozofiju bio drugačiji od Heideggerova. Smatrao je da se njegovo bavljenje filozofijom mora temeljiti na prirodnim znanostima, a po struci bio je psihijatar pa je filozofija bila odlično upotpunjena njegovim znanstvenim bavljenjem duševnim bolestima. U žestokom neslaganju s novokantovcem Rickertom, pojačanom nakon što je 1922. dobio mjesto redovitog profesora filozofije u Heidelbergu, našao je Jaspers potporu u Heideggeru, koji ga je usmjeravao prema utemeljenju filozofske misli nezavisnom od psihijatrije. ${ }^{12}$

\footnotetext{
Max Scheler, Gesammelte Werke, sv. 9: Späte Schriften, Bern 1976., 7-71. O Heideggerovu odnosu spram svoga učitelja Husserla i Schelera v. Karl PögGeler, Heidegger in seiner Zeit, München 1989., 9-11, 32-33.

8 Martin Heidegger, Gesamtausgabe, I: Veröffentlichte Schriften 1910-1976, sv. 3: Kant und das Problem der Metaphy$s i k$, Frankfurt am Main 1991., XVI.

9 Isto, 1, 8-17.

10 Isti, Gesamtausgabe, I: Veröffentlichte Schriften 1910-1976, sv. 2: Sein und Zeit, Frankfurt am Main 1977., 3-53.

11 Isti, Sein und Zeit, 310-311, 314-354; Karl Lenmann, Der Tod bei Heidegger und Jaspers, Heidelberg 1938., 13-14, 22-32. Usp. i Ivan Kordić, „Bitak za smrt kao prolaz prema istini bitka“, Bitak i vrijeme. Interpretacije (ur. Damir Barbarić), Zagreb 2013., 89-123.

12 Ukratko o Jaspersu v. Richard Wisser, „Jaspers, Karl“, NDB, sv. 10, Berlin 1974., 362-365.
} 
Glavno Jaspersovo filozofsko djelo, u kojemu je njegovo promišljanje smrti razjašnjeno unutar opsežnog filozofskog sustava, nazvano je Philosophie, a objavljeno je u tri sveska 1932. godine. Jaspers u svome filozofiranju počinje od bitka. Jedan je određen pojam bitka također i egzistencija, „izvor, iz kojega mislim i djelujem“, pokazatelj koji ukazuje na onostranost sve predmetnosti, koja ne može biti predmet istraživanja nego se opisuje samo u vlastitom dijalektičkom kretanju. ${ }^{13}$ Smrt se u Jaspersovoj filozofiji pojavljuje u graničnoj situaciji, odnosno svijesti da se ni u jednoj situaciji ne može živjeti bez borbe i patnje, da je potrebno na sebe preuzeti teret i da svatko mora umrijeti. Granične situacije ne mogu se obuhvatiti u filozofiranju, nego pojedinačnim ispunjenjem u vlastitu tubitku kojim egzistencija postaje sebi izvjesna. Smrt kao činjenica još nije granična situacija; ona je nemisliva i neiskusiva jer sve što se o njoj misli samo su negacije, nikada pozitiviteti zato što je ona uvijek smrt bližnjega ili vlastita smrt. Smrt, prema Jaspersu, otvara pitanje konačnosti, relativizira tubitak i pokazuje njegove granice, što vodi do straha i očajanja, ali se iz njih izdiže hrabrost i skok za ostvarenjem smislenoga života. Dokazivanje egzistencije prema smrti uvijek je dijalektičko kretanje između ekstrema, ataraksije i nihilizma. ${ }^{14}$

Shvaćanje smrti ima mnogo zajedničkih točaka u filozofiji Heideggera i Jaspersa. Slično novokantovstvu, oni u smrti ne vide točku prijelaza na drugi svijet, nego katalizator ispunjenja vlastite egzistencije, odnosno ostvarenja smislenog života na ovome svijetu. Kao u kakvu starogermanskom epu, smrti, prema njihovu shvaćanju, treba hrabro „pogledati u oči“ radi oslobođenja od egzistencijalne brige, straha i očajanja. Zbog toga je sasvim jasno da njihova filozofija ostaje zatvorena temi kršćanske eshatologije.

\section{Novokantovstro i psihologija U ZIMMERMANNOVU OPUSU}

Utjecajan hrvatski katolički mislilac Stjepan Zimmermann ${ }^{15}$ cijeloga će se života baviti Kantovom filozofijom, koju je smatrao ključnom i za modernu filozofiju i za teologiju. $\mathrm{Na}$ svoje radove o Kantu bio je posebno ponosan. Primjerice, bliskome je prijatelju, hrvatskome filologu Stjepanu Ivšiću, ${ }^{16}$ prilikom predaje jednoga takva rada za tisak poručio da nigdje neće „naći takav portret ili skicu o Kantu“. ${ }^{17}$ Rado je provodio vrijeme u dugim razgovorima o misli i važnosti njemačkog filozofa. ${ }^{18}$

13 Karl Jaspers, Philosophie, sv. 1: Philosophische Weltorientierung, Berlin 1956., 1-24; K. Lehmann, Der Tod bei Heidegger und Jaspers, 16.

14 Karl Jaspers, Philosophie, sv. 2: Existenzerhellung, Berlin 1956., 201-210, 220-229; K. Lehmann, Der Tod bei Heidegger und Jaspers, 32-44.

15 Ukratko o Zimmermannu v. Ivan TADIĆ, Filozofska misao Stjepana Zimmermanna. Izabrani vidovi s bibliografjom, Split 2010., 9-24, zatim (emotivno, ali dobronamjerno) Željko PAvić, „Pogovor. Život kao ostavština i oporuka“, u: Stjepan Zimmermann, Humanizam i totalitarizam, Virovitica 2003., 115-134 i kratku kronologiju njegova života na str. 139. O Ivšiću v. Josip Lisac - Eduard Hercigonja, „Ivšić, Stjepan“, Hrvatski biografski leksikon (dalje: HBL), sv. 6, Zagreb 2005., 208-210.

17 Nacionalna i sveučilišna knjižnica (dalje: NSK), R4836b, Stjepan Zimmermann Stjepanu Ivšiću, s. a.

18 NSK, R6125a, Zdenko Vernić Stjepanu Zimmermannu, 7. 9. 1926. 
Zimmermann se Kantom počeo baviti prije Prvoga svjetskog rata. Zaintrigirala ga je njegova misaona veličina i privlačan skolastički način izlaganja kojim je došao do rezultata poprilično drugačijeg od onoga koji je naučavala skolastička teorija, a posebice tvrdnja o ograničenosti ljudske spoznaje na svijet iskustva, što je značilo da se razumom ne može dokazati postojanje Boga. ${ }^{19}$ Već se iz prvoga Zimmermannova rada vidi da je njegovo razumijevanje Kanta bilo pod utjecajem tada prevladavajuće paradigme u njemačkoj filozofiji, novokantovstva. Baš poput novokantovaca, kao cilj Kantova kritičkog projekta naveo je istraživanje uvjeta mogućnosti spoznaje, tvrdio je da filozof iz Königsberga utemeljenjem praktičke filozofije na noumenalnom svijetu naginje idealističkom dogmatizmu, a glavni je problem u njegovoj filozofiji vidio u stvari po sebi. ${ }^{20}$ Upravo su i neke esencijalne Zimmermannove kritike Kantu preuzete iz novokantovske tradicije, poput prigovora Kantovu subjektivizmu, nedokazivosti kategoričkog imperativa i racionaliziranju vjere. ${ }^{21}$

Međutim, iako je Zimmermannovo shvaćanje Kanta bilo oblikovano novokantovstvom, on je takvu filozofiju iz spomenutih razloga posve odbijao sa stajališta katoličkog intelektualca vjernog skolastičkoj tradiciji. ${ }^{22}$ Zanimljivo je (u kontekstu Heideggerove knjige Kant und das Problem der Metaphysik) da je on protiv novokantovaca tvrdio kako se ljudska spoznaja zasniva na ontološkim načelima, iz čega je zaključivao da znanstvena spoznaja može prelaziti granice iskustva. ${ }^{23}$ Oslanjajući se na učenje sv. Tome Akvinskog i na tada suvremene interpretatore njegove misli, Zimmermann je pobijao Kantovu spoznajnu teoriju, ${ }^{24}$ okrunivši svoj višegodišnji rad dvodijelnom knjigom Kant i neoskolastika (1920./1921.). ${ }^{25}$

Iz istih se religioznih pobuda Zimmermann počeo baviti noetikom, koja je davala odgovor na pitanje je li moguće dobiti „sigurni, konačni odgovor“ na životna pitanja ${ }^{26}$ te, konačno, psihologijom jer ona uključuje pitanje slobodne volje, odnosno duše. ${ }^{27}$ Iako je priznavao „važnost empiričke psihologije uopće za sve umske znanosti“, pa tako i religiju, „a u području specijalne filozofije za logiku, etiku i napose za spekulativnu psihologiju“,

19 O svome prvom susretu s Kantovom filozofijom sâm Zimmermann kaže: „Tako sam kao šestoškolac čuo od jednog maturanta ovu izjavu: 'Ne može se dokazati, da ima Boga. To je dokazao najveći filozof, Kant.' Ne mogu zaboraviti potlačnog dojma, što su ga te rieči učinile na me. Bile su tako uvjerljivo izrečene, da se u meni kao nešto srušilo i kao da se u temelju potreslo nešto, za što nisam ni znao, da mi služi uporištem života." Usp. Stjepan Zimmermann, Putem života. Autoergografija, Zagreb 1945., 57.

20 Isti, „Znanje i vjera u Kantovoj filozofiji“, Bogoslovska smotra, 5/1914., 13-26.

21 Istı, „Moral i religija u Kantovoj filozofiji“, Bogoslovska smotra, 5/1914., 138, 288, 380.

22 Istı, „J. Hessen. Die Religionsphilosophie des Neukantianismus. 2. izd. Herder“, Bogoslovska smotra, 12/1924., $504-505$.

23 IsTI, „Znanstvena vrijednost metafizičke spoznaje“, Bogoslovska smotra, 9/1918., 199, 278.

24 Isti, „Kantova i skolastička teorija uzročnosti“, Bogoslovska smotra, 7/1916., 136-155, 237-253; Isti, „Pojam istine u Kantovoj i skolastičkoj filozofiji“, Bogoslovska smotra, 8/1917., 17-27, 121-131; Istı, „Teleološki princip u Kantovoj i skolastičkoj filozofiji“", Bogoslovska smotra, 8/1917., 197-209, 301-315. Svaki od tih članaka tendenciozno želi pokazati prednost skolastičke nad Kantovom filozofijom po temama u naslovu, a posljednja dva pogotovo glede Kantova i Humeova odnosa. Za noviji prikaz odnosa potonje dvojice mislioca usp. M. GLOBAČniK, Izazov skepticizma.

25 Stjepan Zimmermann, Kant i neoskolastika, sv. 1: Sustavno-kritički, Zagreb 1920. i sv. 2: Studije, Zagreb 1921. Prvi dio razlaže Kantovu teorijsku i praktičku filozofiju, uz poneke usporedbe s novoskolastičkim učenjem, dok drugi sadrži neke (i u ovome radu citirane) članke već objavljene u Bogoslovskoj smotri. I nakon te je knjige Zimmermann nastavio pobijati Kantovu filozofiju s novoskolastičke pozicije. Usp., primjerice, Isti, „O načelu uzročnosti“, Bogoslovska smotra, 13/1925., 144-155.

26 Isti, „Metafizička ideologija“, Bogoslovska smotra, 7/1915., 291.

27 Isti, „O slobodnoj volji“", Bogoslovska smotra, 6/1915., 34-35, 48, 152, 342. 
ipak je uvijek tražio način kako dokazati skladnost moderne znanstvene psihologije s aristotelovskim, odnosno novoskolastičkim načelima. ${ }^{28} \mathrm{Njegov}$, u pravilu britak, način odbacivanja učenja koja nisu bila u skladu s novoskolastikom, vodio ga je u javne debate $s$ onima kojima je smetao njegov izraženo religijski svjetonazor u temama koje su se ticale suvremene znanosti. ${ }^{29}$

\section{ZiMMERMANNOVO SHVAĆANJE SMRTI I NJEGOVA RECEPCIJA NJEMAČKE FILOZOFIJE EGZISTENCIJE U} MEĐURATNOME PERIODU

Kršćanski svjetonazor koji je obilježio Zimmermannovo proučavanje psihologije i Kantove filozofije bio je paradigmatičan za cjelokupan njegov opus. Uvjeren u skolastičke (a priznajući i Kantom nadahnute) dokaze o postojanju Boga, ${ }^{30}$ snažno je naglašavao centralnu ulogu Katoličke crkve kao božanske institucije u povijesti i sadašnjosti ljudske civilizacije. ${ }^{31}$ Zbog toga je smrt za Zimmermanna mogla biti samo prijelazna točka na drugi svijet. Samu je smrt shvaćao biološki, kao „prestanak organskog djelovanja“, te je ona bila podređena kršćanskome pojmu „vječnoga života“. ${ }^{2}$

Dakle, u krucijalnim temama koje su spajale Zimmermanna s Heideggerom i Jaspersom, u psihologiji, pitanju ocjene Kantove filozofije i odnosu prema smrti, oni su bili različitih mišljenja. Kao strastven pratitelj njemačke filozofije, ${ }^{33}$ Zimmermann je dobro poznavao mi-

28 Isti, „Novi udžbenik za eksperimentalnu psihologiju“, Bogoslovska smotra, 7/1916., 73, 82; Isti, „Volja kao faktor u duševnom životu“, Bogoslovska smotra, 6/1915., 388, 390.

29 Zimmermann je bio u sporu s poznatim hrvatskim psihologom Ramirom Bujasom (1879. - 1959.), o kojemu v. Želimir Pavlina, „Bujas, Ramiro“, HBL, sv. 2, Zagreb 1989., 451-453. Zimmermannova je knjiga Duševni život bila 1932. predmet javne debate s filozofom Zdenkom Vernićem (1885. - 1944.), koji ga je nepristojno optuživao da pod plaštem znanstvenog djela širi katoličku propagandu. Vernić je potjecao iz stare plemićke obitelji iz okolice Zagreba (čija se ostavština čuva u Hrvatskom državnom arhivu [dalje: HDA]), a u međuratnom razdoblju, kako se navodi na Arhinetu, bio je „urednik izvještajne agencije 'Zeta' (1926-1928), izdavač Književnih novina, te direktor izvještajne agencije 'Croatia"“ (http://arhinet.arhiv.hr/details.aspx?ItemId=3_11205). Vernić je svoje drugačije shvaćanje aristotelizma, tomizma, psihologije i pogotovo Kanta (shvaćanje kojega stoji „pod jednom lošom i neopravdanom impresijom njemačkih povijesti filozofija“, neutemeljeno smatra Vernić) izložio Zimmermannu u već citiranom izvoru: NSK, R6125a, Vernić Zimmermannu, 7. 9. 1926. Ukratko o sporu Zimmermanna, Bujasa i Vernića v. Ljudevit HanžEK, „Zimmermannova polemika s Vernićem i Lachom“, Prilozi za istraživanje hrvatske filozofske baštine, 39/2013., 315321, koji ipak ne zna za ovdje spomenuto pismo.

Stjepan ZimmermanN, „Vrijednost deontološkog dokaza za egzistenciju Božju“, Bogoslovska smotra, 12/1924., 273285.

31 Isti, „Ideologija kršćanstva“, Bogoslovska smotra, 18/1930., 407-414.

32 Isti, „Sa područja filozofije“, Bogoslovska smotra, 12/1924., 370-375. U ovome se zanimljivu tekstu (odgovoru svojim učenicima, vjerojatno u vezi s njegovom knjigom Temelji psihologije iz 1924.) Zimmermann bavi evolucionizmom, životinjskom dušom i drugim temama.

33 Kako je revno Zimmermann nabavljao tada teško pristupačnu literaturu, što se vidi u njegovim djelima i brojnim recenzijama, pokazuje i primjer s hrvatskim filozofom Franjom Markovićem: „Našao je u mojem tekstu citate iz Tiedemannova 'Theäteta' (1794.) i Reinholdovih 'Briefe über Kantische Philosophie' (1790.) i upozorio me, da ne smijem citirati, što nisam čitao, a te su knjige nepristupačne, jer su izašle brzo nakon Kantove Kritike. Međutim, ja sam mu ih odmah pružio (antikvarno sam ih dobio nakon dvogodišnjeg traganja po njemačkim knjižarama)." S. ZIMMERMAN, Putem života, 72. Slično je (posudbom i kupovanjem) nabavljao i knjige iz psihologije, kako se vidi iz njegove korespondencije s Elzom Kučera: NSK, R4771b, pismo Stjepana Zimmermanna Elzi Kučera, 1932.? Usp. i HDA, fond Blaž Jurišić, kut. 8, pismo br. 2244, Stjepan Zimmermann Blažu Jurišiću, 6. 12. 1934. 
slioce koji će presudno utjecati na filozofiju egzistencije, Husserla i Schelera. ${ }^{34}$ Međutim, iz spomenutog razloga razilaženja u mišljenju, Heideggera i Jaspersa u međuratnom razdoblju gotovo nikada ne spominje. ${ }^{35}$ Zasigurno su mu Jaspersova sekularna znanstvena psihijatrija i njegova filozofija egzistencije te Heideggerova fundamentalna ontologija (a time i njegova reinterpretacija Kanta u takvu ključu), u kojima je smrt postala odrednica ovozemaljskoga, umjesto onozemaljskoga života, bile neprihvatljive. Kada Zimmermann spomene Heideggera ili Jaspersa, onda su njegove izjave, nadahnute oprekom između njihove „filozofije života" i njegove novoskolastičke filozofije (vječnoga) života, kratke i oštre:

Suvremena kriza duha, koju već nazivamo agonijom, sastoji [se] u kaosu na području spoznajne orijentacije o životu. Izgubljena je smjernica u snalaženju na putovima života. Heideggerovska tragična eksistencija, Kierkegaardova tmurnost, Nietzscheovski rasizam, Marxov ekonomski kolektivizam - sve su to oblici današnjeg života, u kojima je nestao njegov smisao. Da takvu tvrdnju možemo postaviti, treba za to pružiti valjanu opravdanost. U tome je znanstveni zadatak filozofije života. Hoćemo li dakle dati nauku o smislu života, moramo tu nauku postaviti na logične temelje, a time će dobiti svoje opravdanje određeni smisao života. ${ }^{36}$

\section{Slično će napisati i u završnom razmatranju zbirke ogleda Kriza kulture (1943.):}

Banalnost skolastičkih protivnika zauzima kadgod tako zastrašujuće razmjere, da oni skolastičku filozofiju naprosto proglasuju bez dodira sa životom, - jer ju zastupaju uglavnom samostanci. Pritom oni čak zaboravljaju, da su teističku etiku (filozofiju život[a]) „uglavnom" zastupali već Platon i Aristotel, pa nebrojeni skolastici nesamostanci, i također neki neskolastički filozofi. Osim toga, ovi protuskolastici jamačno ograničuju filozofiranje o životu na onaj smjer novovječne filozofije, koji je u poviestnom nazivlju poznat kao „filozofija života“ $i$ „,filozofija eksistencije“; no time bi ukupna poviest filozofije postala više nego jedan torzo. (Kierkegaard - Dilthey - Jaspers - Heidegger ne znače ipak jedinu filozofiju o životu.) To je, uostalom, samo jedan primjer utopljeničke slamke, o koju se vješaju nepoznavaoci skolastičke filozofije, kako bi time nadomjestili odsutnost kritičke spreme u zastupanju ateističkog nazora o životu. ${ }^{37}$

34 Zimmermann pozitivno navodi Husserla već 1918. (iako, bio to tipfeler ili ne, piše Hasserl: S. Zimmermann, „Znanstvena vrijednost metafizičke spoznaje“, 198), u kontekstu potvrde „skolastičke nauke“ od strane intencionalne psihologije. Scheler mu je zanimljiv kao katolički mislilac, iako ga i kritizira. Usp. Istı, „Fenomenologija religije“, Bogoslovska smotra, 12/1924., 489-491.

35 Ivan Čehok tvrdi da je Zimmermann navodio Jaspersa u bibliografiji djela Duševni život (1932.) - međutim, Jaspersa u bibliografiji toga djela nema. Usp. I. Čенок, „Filozofijska ostavština“, 196; Stjepan Zıмmermann, Duševni život, Zagreb 1932., 305-306. Jedan od rijetkih koji je na hrvatskome jeziku prikazao Jaspersovu filozofiju u međuratnom periodu bio je budući ustaški ministar Julije Makanec. On je oduševljeno prikazao Jaspersovu knjigu Die geistige Situation der Zeit (1931.) kao ,apel na čovjeka, da se sjeti, da je u velikoj mjeri on sam tvorac svoje sudbine, tvorac svojih katastrofa i pobjeda", što sigurno nije bilo u skladu s Zimmermannovim teološkim shvaćanjima. Usp. Julije MaKanec, „Jaspersova filozofija današnjice“, Hrvatska revija, 8/1935., 252-258, 320-325.

36 Stjepan Zimmermann, Filozofjja života, Zagreb 1941., 272. Predgovor knjizi pisan je na Duhove 1941., ali je ona rezultat Zimmermannovih promišljanja iz međuratnog perioda.

37 Isti, Kriza kulture. Kulturno-filozofijske studije iz suvremene socijalne filozofije, Zagreb 1943., 267-268. Radi se o zbirci ogleda koji su, kao i Filozofija života, dobrim dijelom produkt Zimmermannovih razmišljanja iz međuratnog perioda. 
Ovakvi su Zimmermannovi stavovi identični onima u djelu Jaspersov egzistencijalizam, ${ }^{38}$ u kojemu će također tematizirati problem smrti. ${ }^{39}$ Treba napomenuti da su pored filozofskih nesuglasica postojala i političko-ideološka razilaženja s Heideggerom jer je Zimmermann, „čim su počeli Hitlerovi progoni“, iz protesta prekinuo svaku suradnju s Društvom prijatelja Njemačke, koje je sâm utemeljio u Jugoslaviji, a 1941. godine, nekoliko mjeseci nakon proglašenja Nezavisne Države Hrvatske, vidjevši potpunu nemogućnost da učini bilo što dobroga u toj marionetskoj tvorevini, i s ustašama. ${ }^{40}$

\section{ZAKLJUČAK}

Početkom 20. stoljeća europski su filozofi dobrim dijelom svoj nazor određivali prema novokantovstvu kao prevladavajućoj paradigmi u filozofiji. Ono je uključivalo brojna pitanja koja su se, među ostalim, ticala metafizike, spoznajne teorije, etike i psihologije, u što je bila uključena i tema smrti. Prirodno je stoga da su sve spomenute teme u međuratnome periodu spajale Heideggera i Jaspersa, kao znamenite predstavnike njemačke filozofije egzistencije, i Stjepana Zimmermanna, koji će poslije Drugoga svjetskog rata dovršiti djelo Jaspersov egzistencijalizam. Međutim, dok je Heidegger pozitivno vrednovao Kantovo nasljeđe kroz prizmu fundamentalne ontologije, koja je bila u temelju njegove filozofije, i dok je Jaspersov egzistencijalizam dobivao poticaje iz njegova znanstvenog bavljenja psihijatrijom, Zimmermann je u duhu skolastičke filozofije posve pobijao Kanta, a psihologijom bavio se zbog njezinih implikacija na kršćanski nauk, pogotovo na pitanje duše i slobodne volje. Iz toga proizlazi i drugačije shvaćanje smrti, koja je u Heideggera i Jaspersa odred-

38 Isti, Jaspersov egzistencijalizam, sv. 1, 608: „Šta Jaspers drži o kršćanskom vjerniku, vrlo dobro znamo, - dosta je podsjetiti na njegova bazelska predavanja četrdesetsedme (Der philosophische Glaube). Nije li tamo jasno rekao, da treba napustiti religiju, koja u Isusu vidi Boga? A za objavljene istine, u koje kršćanin vjeruje, nije li rekao da smatrati njihovo važenje ekskluzivnim, znači za ljude zlo (Unheil), i da je takva pretenzija smrtonosna (tödlich)?" Više o odnosu Zimmermanna prema Jaspersu u citiranome djelu v. Željko PAvić, „Čovjekovo opstojanje između egzistencije i transcendencije. Zimmermannova rasprava s filozofijom egzistencije K. Jaspersa“, Zivot i djelo Stjepana Zimmermanna (ur. Vladimir Stipetić), Zagreb 2002., 89-123. Pavić zaključuje da Zimmermann „nije uspio pokazati onu otvorenost za komunikaciju, nego se u mnogim slučajevima zadržao na pukom etiketiranju Jaspersove pozicije. (...) Monološki ton, koji često odzvanja Zimmermannovim interpretacijama, nije dopustio da se čuje glas Drugog, a time niti to da nešto važi protiv njega, odnosno protiv njegove vlastite filozofske pozicije." Isto, 122.

39 NAZ, SZ, kutija "Jaspers“, Jaspersov egzistencijalizam, sv. 2. Ovaj neobjavljen drugi svezak sadrži više od 600 stranica strojopisnoga teksta, a pisan je u obliku dijaloga između trojice filozofa: egzistencijalista Jaspersove orijentacije, filozofa života i novoskolastika. Već na drugoj stranici filozof života pita egzistencijalista u čemu nalazi „tamne, negativne strane života“, na što mu ovaj odgovara: „Ja mogu svakog trenutka biti mrtav!“ Tema smrti vraća se i dalje na različitim mjestima u dijalogu $(285,331,410,458)$. Dakako, smrt je u Zimmermannovu djelu uvijek povezana s pitanjem postojanja Boga, besmrtnosti duše i kršćanske etike, što uvijek povlači njegove stare probleme iz spoznajne teorije (a time i Kantove filozofije), psihologije, noetike itd. Na str. 154 tako novoskolastik tvrdi da u pitanju postojanja Boga „dobiva svoje pravo značenje smrt! Sad je posve jasno kako čovjek strepi pred smrću - ne samo kao fizičkom prestanku života, nego u moralnom značenju, jer se čovjek pita: kako li će mi biti suđeno na pragu posmrtnog života?" Slično i na str. 219 novoskolastik tvrdi kako, s obzirom na to da postoje slučajevi kada zločince njihovi zločini čine sretnima, „dok moralno vrijedan čovjek i stradava: mora biti posmrtni život, primjeren moralnosti pojedinca, kao njegova nesreća ili sreća“.

40 S. Zimmermann, „Autobiografske zabilješke iz doba rata i poslije rata“, Humanizam i totalitarizam, 21-22, 28-29. Njegov javni napad na ustašku strahovladu bio je vrlo znakovit u ogledu nazvanom „Kako će filozofija kulture prosuđivati našu sadašnjost?“, Kriza kulture, 68-112. 
nica života na ovome svijetu, dok je ona u Zimmermanna tek biološka činjenica i prijelaz prema životu poslije smrti.

Iz svega izloženog u ovome radu, moguće je složiti se s time da je Jaspersovo „mišljenje kasna tema Zimmermannove filozofije “" ${ }^{41}$ ali se idejni izvori Zimmermannova polemičkog, opsegom najvećeg i do danas u punom obujmu neobjavljenog djela Jaspersov egzistencijalizam, koje je dovršeno nakon Drugoga svjetskog rata, nalaze već u međuratnom razdoblju, u razlici filozofskih nazora, a time i različitom shvaćanju smrti Zimmermanna s jedne te Heideggera i Jaspersa s druge strane.

\section{$\cos$}

\section{Literatura}

\section{Izvori}

Hrvatski državni arhiv

Fond Blaž Jurišić (HR-HDA-803)

Nacionalna i sveučilišna knjižnica u Zagrebu

R4771b: Korespondencija Elza Kučera - Stjepan Zimmermann

R4836b: Korespondencija Stjepan Ivšić - Stjepan Zimmermann

R6125a: Korespondencija Zdenko Vernić - Stjepan Zimmermann

Nadbiskupijski arhiv u Zagrebu

Ostavština Stjepana Zimmermanna

\section{Primarna literatura}

Martin Heidegger, Gesamtausgabe, I: Veröffentlichte Schriften 1910-1976, sv. 2: Sein und Zeit, Frankfurt am Main 1977.

Martin Heidegger, Gesamtausgabe, I: Veröffentlichte Schriften 1910-1976, sv. 3: Kant und das Problem der Metaphysik, Frankfurt am Main 1991.

Martin Heidegger - Karl Jaspers, Briefwechsel 1920-1963, Frankfurt am Main 1990.

Karl Jaspers, Philosophie, sv. 1: Philosophische Weltorientierung, Berlin 1956.

Karl Jaspers, Philosophie, sv. 2: Existenzerhellung, Berlin 1956.

Blaž Jurišić, Dnevnik Blaža Jurišića (prir. Biserka Rako), Zagreb 1994.

Julije MaKaneC, „Jaspersova filozofija današnjice“, Hrvatska revija, 8/1935., 252-258, 320-325.

Max Scheler, Gesammelte Werke, sv. 2: Formalismus in der Ethik und materiale Wertethik, Bern 1966.

Max Scheler, Gesammelte Werke, sv. 9: Späte Schriften, Bern 1976.

Stjepan Zimmermann, Duševni život, Zagreb 1932.

Stjepan Zimmermann, „Fenomenologija religije“, Bogoslovska smotra, 12/1924., 489-491.

$\overline{41}$ I. ČEнок, „Filozofijska ostavština“, 196. 
Stjepan Zimmermann, Filozofija života, Zagreb 1941.

Stjepan Zimmermann, Humanizam i totalitarizam, Virovitica 2003.

Stjepan Zimmermann, „Ideologija kršćanstva“, Bogoslovska smotra, 18/1930., 407-414.

Stjepan Zimmermann, Jaspersov egzistencijalizam. Karl Jaspers prema religiji, Zagreb 2002.

Stjepan ZimmermanN, „J. Hessen. Die Religionsphilosophie des Neukantianismus. 2. izd. Herder", Bogoslovska smotra, 12/1924., 504-505.

Stjepan Zimmermann, Kant i neoskolastika, sv. 1: Sustavno-kritički, Zagreb 1920.

Stjepan Zimmermann, Kant i neoskolastika, sv. 2: Studije, Zagreb 1921.

Stjepan Zimmermann, „Kantova i skolastička teorija uzročnosti“, Bogoslovska smotra, 7/1916., $136-155,237-253$.

Stjepan Zimmermann, Kriza kulture. Kulturno-filozofijske studije iz suvremene socijalne filozofije, Zagreb 1943.

Stjepan Zimmermann, „Metafizička ideologija“, Bogoslovska smotra, 7/1915., 291-301.

Stjepan Zimmermann, „Moral i religija u Kantovoj filozofiji“, Bogoslovska smotra, 5/1914., 122 139, 270-289, 369-384.

Stjepan Zimmermann, „Novi udžbenik za eksperimentalnu psihologiju“, Bogoslovska smotra, 7/1916., 73-85.

Stjepan Zimmermann, „O načelu uzročnosti“, Bogoslovska smotra, 13/1925., 144-155.

Stjepan ZimmermanN, „O slobodnoj volji“, Bogoslovska smotra, 6/1915., 33-50, 149-169, 228 249, 341-361.

Stjepan Zimmermann, „Pojam istine u Kantovoj i skolastičkoj filozofiji“, Bogoslovska smotra, 8/1917., 17-27, 121-131.

Stjepan Zimmermann, Putem života. Autoergografija, Zagreb 1945.

Stjepan Zimmermann, „Sa područja filozofije“, Bogoslovska smotra, 12/1924., 370-375.

Stjepan Zimmermann, „Teleološki princip u Kantovoj i skolastičkoj filozofiji“, Bogoslovska smotra, 8/1917., 197-209, 301-315.

Stjepan ZimmermanN, „Volja kao faktor u duševnom životu“, Bogoslovska smotra, 6/1915., 388 397.

Stjepan ZimmermanN, „Vrijednost deontološkog dokaza za egzistenciju Božju“, Bogoslovska smotra, 12/1924., 273-285.

Stjepan Zimmermann, „Znanstvena vrijednost metafizičke spoznaje“, Bogoslovska smotra, 9/1918., 1-7, 97-102, 193-202, 275-279.

Stjepan Zimmermann, „Znanje i vjera u Kantovoj filozofiji“, Bogoslovska smotra, 5/1914., 13-26.

\section{Sekundarna literatura}

Frederick Charles BeIser, The Genesis of Neo-Kantianism, 1796 - 1880, Oxford 2014.

Frederick Charles BeIser, „Weimar Philosophy and the Fate of Neo-Kantianism“, Weimar Thought. A Contested Legacy (ur. Peter A. Gordon i John P. McCormick), Princeton 2013., 115-132.

Ben Bradley - Fred Feldman - Jens Johansson, „Introduction. Philosophy of Death“, The Oxford Handbook of Philosophy of Death (ur. Ben Bradley, Fred Feldman i Jens Johansson), Oxford 2013., 1-4.

Ulrich Claesges, „Husserl, Edmund“, Neue Deutsche Biographie, sv. 10, Berlin 1974., 87-89

Ivan Č̈нок, „Filozofijska ostavština Stjepana Zimmermanna“, Prilozi za istraživanje hrvatske filozofske baštine, 19/1993., 193-207. 
Matko Globačnik, Izazov skepticizma. Utjecaj Humeove metafizike i moralne filozofije u Europi 18. stoljeća, Zagreb 2016.

Ljudevit HanžEx, „Zimmermannova polemika s Vernićem i Lachom“, Prilozi za istraživanje hrvatske filozofske baštine, 39/2013., 315-328.

Wolfhart Henckmann, „Scheler, Max“, Neue Deutsche Biographie, sv. 22, Berlin 2005., 644-646.

Ivan Kordić, „Bitak za smrt kao prolaz prema istini bitka“, Bitak i vrijeme. Interpretacije (ur. Damir Barbarić), Zagreb 2013., 127-159.

Karl Lehmann, Der Tod bei Heidegger und Jaspers, Heidelberg 1938.

Josip Lisac - Eduard Hercigonja, „Ivšić, Stjepan“, Hrvatski biografski leksikon, sv. 6, Zagreb 2005., 208-210.

Željko PAvić, „Čovjekovo opstojanje između egzistencije i transcendencije. Zimmermannova rasprava s filozofijom egzistencije K. Jaspersa“, Život i djelo Stjepana Zimmermanna (ur. Vladimir Stipetić), Zagreb 2002., 89-123.

Želimir Pavlina, „Bujas, Ramiro“, Hrvatski biografski leksikon, sv. 2, Zagreb 1989., 451-453.

Karl Pöggeler, Heidegger in seiner Zeit, München 1989.

Ivan TADIĆ, Filozofska misao Stjepana Zimmermanna. Izabrani vidovi s bibliografijom, Split 2010. Richard Wisser, „Jaspers, Karl“, Neue Deutsche Biographie, sv. 10, Berlin 1974., 362-365.

\section{Mrežna stranica}

http://arhinet.arhiv.hr/details.aspx?ItemId=3_11205

\section{$\cos$}

\section{DeATH in The German PHILOSOPHy OF EXISTENCE OF THE INTERWAR PERIOID AND ITS RECEPTION IN STJEPAN ZIMMERMAN'S THOUGHT}

The author examines the significance of death in the philosophy of Martin Heidegger and Karl Jaspers, the notable representatives of German philosophy of existence, as well as the way it was received in the thought of Stjepan Zimmerman, within the historical context of the interwar period, when all three thinkers lived and worked. This paper uses the aforementioned topic as a starting point, in order to reveal the notional and historical roots of Zimmerman's magnum opus Jaspersov egzistencijalizam (Jasper's Existentialism), which remains unpublished in its entirety to this day. The three thinkers shared an interest in Kant's philosophical legacy with all its implications, as well as professional involvement in psychology, or rather, psychiatry, and both of those factors directly shaped their views on death. The research for this paper has shown that Heidegger's interpretation of Kant's philosophy based on fundamental ontology, as well as Jaspers's work in psychiatry were at odds with Zimmerman's understanding of Kant, shaped in the Neo-Kantian tradition, and the fact that his work in psychology was religiously motivated. Therefore, Heidegger and Jaspers's understanding of death as an existential determinant of life had to be wholly unacceptable to Zimmerman, who regarded death as a biological fact and a transition into life after death. Adding to this the differences in ideology that he had with Heidegger post-1933, the rare insights 
into Zimmerman's opinions on Heidegger and Jaspers in the interwar period reveal a substantial animosity. This attitude will also be prevalent in Jaspers's Existentialism, the book Zimmerman completed after the Second World War.

Key words: Karl Jaspers, Martin Heidegger, Stjepan Zimmerman, death, the philosophy of existence, Neo-Kantianism, Catholic theology 
